\title{
Prospects of the application of some species of the Lamiaceae family and some features of the development of their tinctures
}

\author{
Oksana Yezerska ${ }^{1}$, Roman Darmograj ${ }^{2}$, Nataliia Hudz $^{1 *}$, Volodymyr Levon $^{3}$ \\ ${ }^{1}$ Danylo Halytsky Lviv National Medical University, Department of Drug Technology and Biopharmaceutics, \\ Lviv, Ukraine \\ ${ }^{2}$ Danylo Halytsky Lviv National Medical University, Department of Pharmacognosy and Botany, Lviv, Ukraine \\ ${ }^{3}$ M.M. Gryshko National Botanical Garden of the National Academy of Sciences of Ukraine, \\ Department of Fruit Plants Acclimatization, Kyiv, Ukraine
}

Article Details:

Received: 2021-03-12

Accepted: 2021-03-25

Available online: 2021-05-31

\begin{abstract}
The search for new powerful herbal products with anti-inflammatory, antimicrobial and antinociceptive activities presents an important area of pharmaceutical research. Some plants of the Lamiaceae family are well-known for their significant antimicrobial, anti-inflammatory, and pain-relieving activities. Species of the Lamiaceae attract a great scientific interest mainly due to the diversity of terpenes and phenolic compounds, including phenolic acids and flavonoids. Essential oils possess certain antimicrobial activity. For experimental studies, we selected four herbs. Among them were Monarda fistulosa L., Satureja hortensis L., Thymus vulgaris L., and Mentha piperita L. Four tinctures of the above-mentioned herbs were elaborated and partly phytochemically evaluated. We established the coefficients of alcohol absorption for the tested raw materials and the maximum absorption for active markers and ticntures after adding aluminum chloride that is needed for the development and standardization of tictures. The solutions of complexes aluminum chloride with quercetin $(20 \mathrm{mg} / \mathrm{L})$, rutin $(50.2 \mathrm{mg} / \mathrm{L})$, and chrysin ( $80 \mathrm{mg} / \mathrm{L})$ had the maximum absorption at the wavelengths of $425.9 \pm 0.3 \mathrm{~nm}$ at $77 \mathrm{~min}$ of the reaction, $412.3 \pm 0.3 \mathrm{~nm}$ at $82 \mathrm{~min}, 388.4 \pm 0.7 \mathrm{~nm}$ at $81 \mathrm{~min}$, respectively. The tinctures of Monarda fistulosa, Satureja hortensis, Thymus vulgaris, and Mentha piperita had the maximum absorption at $391.2 \pm 0.5 \mathrm{~nm}$ at $91 \mathrm{~min}, 389.9 \pm 0.5 \mathrm{~nm}$ at $76 \mathrm{~min}, 391.8 \mathrm{~nm}$ at $83 \mathrm{~min}, 394.9 \pm 1.1 \mathrm{~nm}$ at $78 \mathrm{~min}$, respectively. The carried out spectrophotometric studies confirmed the prevalence of flavones in the tested tinctures, considering the proximity of the maximum absorption of the tested tinctures and chrysin. The next studies will be continued at the standardization of the developed tinctures and the establishment of their antimicrobial activity.
\end{abstract}

Keywords: Monarda fistulosa, Satureja hortensis, Thymus vulgaris, Mentha piperita, ethanolic extracts, essential oil

\section{Introduction}

The search for new powerful anti-inflammatory and antimicrobial herbal products with antinociceptive potential presents an important area of pharmaceutical research (Casian et al., 2020). Some plants of the family of Lamiaceae Lindl. are well-known for their significant antimicrobial, anti-inflammatory and pain-relieving properties (Ben-Arye et al., 2011; Hamidpour et al., 2014; Honcarenko et al., 2019; Casian et al., 2020;
Shanaida et al., 2021a, b). In this context, Monarda fistulosa L., Satureja hortensis L., Thymus vulgaris L., and Mentha $\times$ piperita L. are the subject of several studies in the field of pharmaceutical technology and pharmacology (Thompson et al., 2003; Hamidpour et al., 2014; Liu et al., 2014; Marwa et al., 2017; Fierascu et al., 2018; Shanaida, 2018; Casian et al., 2020; Shanaida et al., 2021a, b).

\footnotetext{
*Corresponding Author: Nataliia Hudz, Danylo Halytsky Lviv National Medical University, Department of Drug Technology and Biopharmaceutics, Str. Pekarska 69, 79010 Lviv, Ukraine $\triangle$ natali gudz@ukr.net
} 
Species of the Lamiaceae attract great attention mainly due to the diversity of monoterpenes (Thompson et al., 2003; Honcharenko et al., 2019; Hudz et al., 2020). It has been revealed that essential oils possess certain antimicrobial activity (Ben-Arye et al., 2011; Rezvanpanah et al., 2011; Honcharenko et al., 2019). Therefore, they could be considered as active substances of potential antimicrobial herbal preparations (Rezvanpanah et al., 2011). The essential oil of Satureja hortensis contains significant amounts of two phenolic ketones: carvacrol and thymol. They are isomeric compounds and contain a phenol group in their structures (Hamidpour et al., 2014). The thymol chemotype of Thymus vulgaris produces thymol (22.4-72.9\%) and carvacrol (0.8-26.8\%) in glandular trichomes on the surface of leaves (Thompson et al., 2003). Carvacrol and thymol have a strong inhibitory effect on the growth of a wide range of microorganisms, including fungi and bacteria (Hamidpour et al., 2014).

Rosmarinic acid is the major compound of the aqueous and ethanolic extracts of Dracocephalum moldavica, Ocimum americanum, Satureja hortensis and other herbs of the Lamiaceae family (Shanaida et al., 2018; Shanaida et al., 2021a). Rosmarinic acid is known for its antiviral, antioxidant, anti-inflammatory, and immunostimulating activities (Hamidpour et al., 2014; Shanaida et al., 2021a). It was established that administration of pure rosmarinic acid at a dose of $25 \mathrm{mg} / \mathrm{kg}$ decreased the carrageenin-induced paw oedema in rats at $6 \mathrm{~h}$ by over $60 \%$. The effect of rosmarinic acid $(25 \mathrm{mg} / \mathrm{kg})$ can be comparable with Trolox $(30 \mathrm{mg} / \mathrm{kg}$ ) and indomethacin $(10 \mathrm{mg} / \mathrm{kg})$, which are known as a strong antioxidant and antiinflammatory substances, respectively (Rocha et al., 2015).

Herbal preparations of some species of the Lamiaceae family (thyme, mint, and oregano) are stated as safe and efficient for the symptomatic treatment of discomfort conditions related to strep throat (Ben-Arye et al., 2011; Wijesundara et al., 2019).

Therefore, the development of herbal preparations with antioxidant, anti-inflammation and antimicrobial activity for the prevention and treatment of inflammatory and infectious diseases of the oral cavity is a topical question of modern medicine and pharmaceutical technology.

\section{Material and methodology}

While carrying out the research, the following methods were used: analysis, synthesis, systematization and comparison for processing published scientific data; technological method (maceration); spectrophotometric method for the development of the analytical procedure of the determination of the total flavonoid content.

\section{Plant material}

Aerial parts of Monarda fistulosa (wild bergamot, bee balm, or horse mint) were collected in 2019 and Satureja hortensis (summer savory), Thymus vulgaris (thyme), and Mentha piperita (peppermint, balm mint, lamb mint) were collected in 2017. All the raw materials were picked up in the flowering stage in the Kherson region (Ukraine). The voucher specimens were deposited at the Herbarium of the Sector of Mobilization and Conservation of Plant Resources of the Rice Institute of the NAAS (Plodove, Kherson region, Ukraine) and at the Department of Analytical and Ecological Chemistry of University of Opole (Poland). The aerial parts of the four herbs were dried and kept at room temperature $\left(15-25^{\circ} \mathrm{C}\right)$ in a dark place before the preparation of the tinctures.

\section{Extraction}

All the tinctures were obtained in a ratio of the herbal substance to a final product as approximately 1 to 10. As a solvent, $70 \%$ ethanol was used. The herbal substance was reduced to pieces. The crushed herbal substance was sieved through suitable sieves with the size of holes of 0.5 and $5.0 \mathrm{~mm}$. Then the ground herbal substance of the size in the range of $0.5-5.0 \mathrm{~mm}$ was mixed with $70 \%$ ethanol. The mixtures stood in closed containers. Maceration was performed at room temperature for 7 days. After this period the residue was separated from the extraction solvent by means of filtration through a paper filter.

\section{Determination of the maximum absorption in differential spectra}

For the determination of the maximum absortption we used the analytical procedure of differential spectrometry provided by Hudz et al. (2017a) for the estimation of the TFC in bee bread and by Hudz et al. (2020) for Satureja montana. $50 \mu \mathrm{L}$ of the developed tinctures were diluted with $50 \%$ ethanol up to $1.0 \mathrm{~mL}$ and was mixed with 1.0 of $2 \%$ solution of aluminum chloride hexahydrate. The mixture was mixed by vortex and incubation was done at room temperature for 70-90 min. The volume of $2 \%$ solution of aluminum chloride was replaced by the same amount of $50 \%$ ethanol in the blank. The measures of all the spectra were carried out for each tincture in triplicate in the range of $360-440 \mathrm{~nm}$. Instead of $50 \mu \mathrm{L}$ of a tincture, 
we used the stock solutions of rutin trihydrate $(1000 \mathrm{mg} / \mathrm{L})$, quercetin dihydrate $(400 \mathrm{mg} / \mathrm{L})$ and $200 \mu \mathrm{L}$ of chrysin $(400 \mathrm{mg} / \mathrm{L})$.

\section{Results and discussion}

Lamiaceae is a large plant family of mostly shrubs and herbs (Hamidpour et al., 2014; Hassanzadeh et al., 2016; Karpova et al., 2020). These plants are popular due to various biological activities, including antioxidant and antimicrobial ones (Rezvanpanah et al., 2011; Li et al., 2014; Karpova et al., 2020). These properties are closely related to a variety of secondary metabolites. Species of the Lamiaceae family are used in folk medicine for many years (Ben-Arye et al., 2011; Karpova et al., 2020). Currently, anti-inflammatory, antitussive, diuretic, anti-asthmatic, antiseptic, antispasmodic, and antipyretic activities of the herbs were revealed. Some species demonstrated even antiviral properties (Karpova et al., 2020; Shanaida et al., 2021a).

Monarda is a genus endemic to North America. This genus embraces annual and perennial flowering plants. Many species are grown as ornamentals in different countries because the flower color ranges from red to pink or light purple. Monarda plants produce a high quantity of essential oil. Monarda fistulosa and M. didyma (oswego tea) have a long history of use as medicinal plants by Native Americans (Francati and Gualandi, 2017).

Monarda fistulosa is commonly known as an annual or perennial medicinal plant. It produces monoterpenes in trichomes located on leaves, calyces, and even flower petals. When these trichomes are broken, the scent of escaping monoterpenes appears almost immediately. Monoterpenes have been used for thousands of years as fragrances and flavors. However, plants use them for a variety of functions, including suppression of plant competitors, repelling herbivores, or attracting pollinators and seed dispersers (Harborne, 1993).

Monarda fistulosa is known for its strong therapeutic effects. Its essential oil is characterized by high antibacterial, antimycotic, and anti-inflammatory activities (Zhilyakova et al., 2009). Wild bergamot is mentioned among plants with a high content of thymol and carvacrol up to $60-70 \%$ in the essential oil. At the same time, it also produces significant amounts of thymoquinone - a substance with antimycotic, anticancerous and antituberculous activity (Casian et al., 2020). For this reason, it could be proposed for the treatment of the throat. Shanaida et al. showed that the major constituent of the methylene chloride extract of Monarda fistulosa was thymol (23.73\%), followed by carvacrol (10.09\%), $p$-cymene (9.74\%), and thymoquinone (8.52 \%) (Shanaida et al., 2021b). Casian et al. (2020) stated about a yield of 12.5-14.5 g from $1 \mathrm{~kg}$ of the dried plant material of Monarda fistulosa and content of 20-32\% of thymoquinone and $23-32 \%$ of thymol and carvacrol.

The genus Satureja L. (savory) embraces about 200 species of herbs and shrubs which are grown mostly in the Europe, Mediterranean region, North Africa, the Canary Islands, South America, and West Asia (Hamidpour et al., 2014). Satureja hortensis is an annual herbaceous crop species, strongly branched, with linear leaves.

Dried summer savory contains approximately $0.2-3.0 \%$ of volatile oil (Hamidpour et al., 2014; Hassanzadeh et al., 2016). The main compounds found in extracts and essential oils of Satureja hortensis are terpenoids, phenolic compounds, flavonoids, tannins, steroids, acids, gums, mucilage, and pyrocatechols (Hamidpour et al., 2014). According to different studies, the main components of the volatile oil of Satureja hortensis are thymol (0.3-28.2\%), $\gamma$-terpinene (15.30-39\%), carvacrol (11-67 \%), $p$-cymene (3.5-19.6\%), $\alpha$-pinene (2.91\%) (Hamidpour et al., 2014; Fierascu et al., 2018). For instance, 18 compounds were identified in summer savory collected in Timis County (western region of Romania) during the growing season of the year 2017. Among them were: $\gamma$-terpinene (37.862\%), o-cymene (15.113\%), thymol (13.491 \%), carvacrol (13.225 \%), (+)-4-carene (6.086 \%), $\beta$-myrcene (3.931\%), $\alpha$-thujene (3.695 \%), $\beta$-caryophyllene (1.496\%), $\beta$-pinene (1.374\%), isothymol (0.645\%), D-limonene $(0.558 \%), \quad \alpha$-thujone $(0.546 \%)$ and camphor (0.521 \%) (Popovici et al., 2019). Rezvanpanah et al. (2011) identified 31 compounds in summer savory of Iranian origin. Among them were: $\gamma$-terpinene (31.95\%), $p$-cymene (2.69\%), thymol (1.11\%), carvacrol (48.69\%), (+)-4-carene (6.086\%), $\beta$-myrcene (1.78\%) (Rezvanpanah et al., 2011).

The leaves of summer savory are rich in phenolic compounds, particularly rosmarinic acid and flavonoids, which provide a high antioxidant capacity of the leaves (Hamidpour et al., 2014; Shanaida et al., 2018).

The methanolic extract obtained by maceration contained rosmarinic acid $(24.9 \mathrm{mg} / \mathrm{g})$, caffeic acid $(1.3 \mathrm{mg} / \mathrm{g})$, naringenin $(1.1 \mathrm{mg} / \mathrm{g})$, isoferulic acid $(220 \mu \mathrm{g} / \mathrm{g})$, and apigenin $(165 \mu \mathrm{g} / \mathrm{g})$ (Fierascu et al., 2018). The high pressure liquid chromatography analysis confirmed the presence of gallic acid, caffeic 
acid, chlorogenic acid, ferulic acid, rosmarinic acid, and flavonoids (rutin, hyperoside, quercitrin, apigenin, quercetin, catechin, and apigenin-7-glucoside) in aqueous extracts of Satureja hortensis herb of Ukrainian origin (Shanaida et al., 2018).

The herbal products obtained from summer savory have antioxidant, antimicrobial, antiparasitic, pesticidal, anti-inflammatory, analgesic, hepatoprotective and anticancer properties (Hamidpour et al., 2014; Fierascu et al., 2018).

Carvacrol, cymene and thymol in the essential oil provide antimicrobial activities against food, plants, and human pathogens (Hassanzadeh et al., 2016). The evaluation of the essential oil obtained from Iranian plants showed good antimicrobial activity against several types of microorganisms, with minimum inhibitory concentration values ranging from $0.06 \mu \mathrm{L} /$ $\mathrm{mL}$ for Candida glabrata to $8 \mu \mathrm{L} / \mathrm{mL}$ for Pseudomonas aeruginosa and minimal lethal concentration values ranging from $0.06 \mu \mathrm{L} / \mathrm{mL}$ for Candida glabrata to $16 \mu \mathrm{L} / \mathrm{mL}$ for Pseudomonas aeruginosa. The results were superior to those obtained for the used reference substances (vancomycin, gentamicin and amphotericin) for all the studied microorganisms, with exception of Pseudomonas aeruginosa (Fierascu et al., 2018).

The antimicrobial mechanism is related to damage in membrane integrity, causing leakage of ions and other cell compounds and eventually death of a microbial cell (Fierascu et al., 2018).

Thymus vulgaris is an aromatic plant, which is used for medicinal and spice purposes almost everywhere in the world (Morales, 2002; Honcharenko et al., 2019). Thymus vulgaris shows a polymorphic variation in monoterpene production, the presence of intraspecific chemotype variation being common in the genus Thymus. The wild thymus grown in southern France had six chemotypes (geraniol, $\alpha$-terpineol, thuyanol-4, linalool, carvacrol, and thymol). Each of these six chemotypes is named after its dominant monoterpene (Thompson et al., 2003).

The chemical structure of the most important compounds of the essential oil of Satureja hortensis and Thymus vulgaris (thymol, carvacrol and $p$-cymene) is presented in Figure 1.

Mentha piperita is a hybrid mint - a cross-species between watermint and spearmint. It is one of the most economically important medicinal and aromatic plants (Shah and Mello, 2004; Liu et al., 2014). The essential oil of this plant possesses antimicrobial, antiinflammatory, antitussive, local anesthetic activities (Shah and Mello, 2004; Ben-Arye et al., 2011).

Marwa et al. (2017) established that the essential oil of Mentha piperita contained menthol (46.32\%), menthofuran (13.18\%), menthyl acetate (12.10\%), menthone (7.42\%), and 1,8-cineole (6.06\%) as the principal constituents. The tested essential oil demonstrated strong inhibitory activity against the tested microorganisms (Escherichia coli ATCC 25922, Pseudomonas aeruginosa ATCC 27853, Micrococcus luteus ATCC 14452, Staphylococcus aureus ATCC 29213, Bacillus subtilis ATCC 6633, Salmonella typhimurium, Bacillus cereus, Candida albicans, and Candida tropicalis. The minimum inhibitory concentrations ranged from 0.062 to $0.5 \%(\mathrm{v} / \mathrm{v})$, except for Pseudomonas aeruginosa. Pseudomonas aeruginosa was the least sensitive and was only inhibited by concentrations as high as $0.5 \%(\mathrm{v} / \mathrm{v})$ (Marwa et al., 2017).

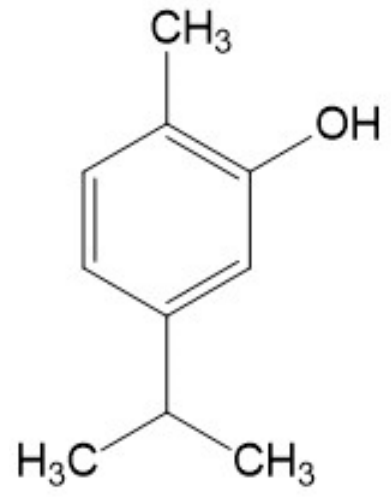

carvacrol

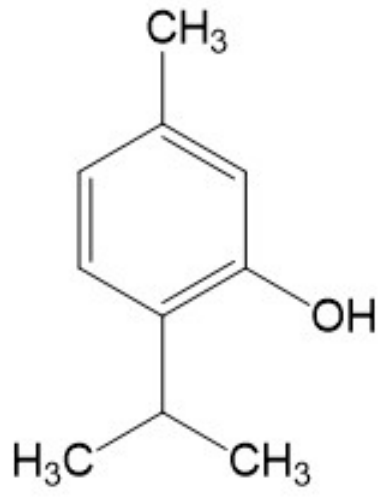

thymol

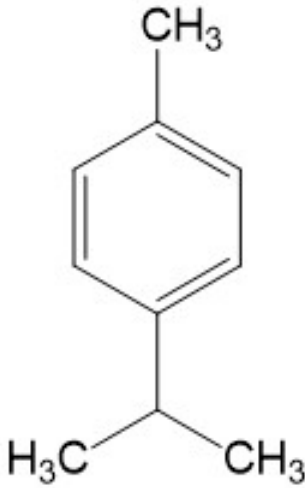

p-cymene

Figure 1

Chemical structure of carvacrol, thymol, and p-cymene 
<smiles>CC(C)[C@H]1CC[C@@H](C)C[C@H]1O</smiles>

(-)-(1R,3S,4S)-menthol

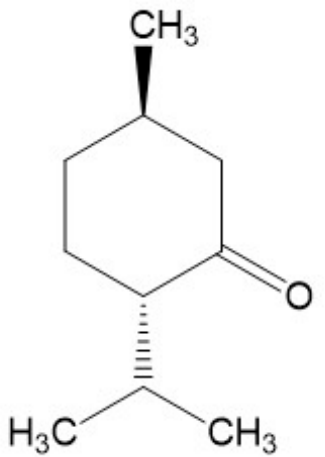

$(-)-(1 \mathrm{R}, 4 \mathrm{~S})-$ menthone<smiles>CC(C)C12CCC(C)(CC1)O2</smiles>

1,8-cineole<smiles>C=C(C)C1CC=C(C)CC1</smiles>

limonene

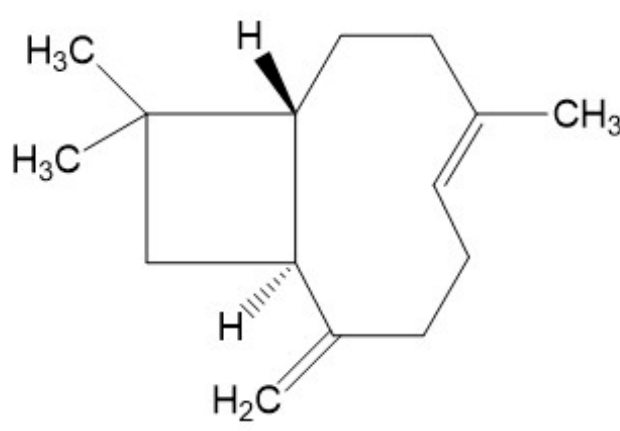

$\beta$-caryophyllene<smiles>C=C(C)C1CC=C(C)C(=O)C1</smiles>

carvone

Figure 2 Active compounds of peppermint essential oil

The chemical structures of the major compounds of the essential oil of Mentha piperita are depicted in Figure 2.

Peppermint is famous for its flavoring and medicinal properties and is used in food, cosmetics, and medicines. It is helpful in symptomatic relief from illnesses such as colds, cramps, indigestion, nausea, sore throat, toothache, or even cancer. Many pharmacologic studies also have shown that peppermint possesses antioxidant, cytotoxic, antiallergenic, antiviral, and antibacterial activities with few side effects (Shah and Mello, 2014).
For experimental studies, we selected four herbs. Among them were Monarda fistulosa, Satureja hortensis, Thymus vulgaris, and Mentha piperita. Four tinctures of the Thymus vulgaris, Satureja hortensis, Mentha piperita, and Monarda fistulosa herb were elaborated. Ethanol absorption coefficient is an important technological parameter in the tincture manufacture. The results of the technological research are presented in Table 1.

It was established that the coefficient of alcohol absorption of the crushed raw material with the size of particles in the range of 0.5 to $5.0 \mathrm{~mm}$ was $2.8 \mathrm{ml} / \mathrm{g}$,

Table 1 Calculations of the experimental determination of the absorption coefficient of $70 \%$ ethanol

\begin{tabular}{|l|c|c|c|c|}
\hline $\begin{array}{l}\text { Name of herb, year of } \\
\text { the collection }\end{array}$ & $\begin{array}{c}\text { Mass of } \\
\text { a crushed raw } \\
\text { material (g) }\end{array}$ & $\begin{array}{c}\text { Volume of 70 \% } \\
\text { ethanol for the } \\
\text { extraction (m) }\end{array}$ & $\begin{array}{c}\text { The amount of the } \\
\text { tincture obtained } \\
\text { after absorption (m) }\end{array}$ & Calculations \\
\hline Thymus vulgaris, 2017 & 7.5 & 100 & 79.0 & $\mathrm{X}_{1}=(100-79): 7.5=2.80 \mathrm{ml} / \mathrm{g}$ \\
\hline \multirow{2}{*}{$\begin{array}{l}\text { Satureja hortensis, } \\
\mathbf{2 0 1 7}\end{array}$} & 4.1 & 58 & 40.5 & $\mathrm{X}_{2}=(58-40,5): 4.1=4.30 \mathrm{ml} / \mathrm{g}$ \\
\cline { 2 - 5 } Mentha piperita, 2017 & 5.5 & 78 & 55.0 & $\mathrm{X}_{2}=(78-55): 5.5=4.20 \mathrm{ml} / \mathrm{g}$ \\
\hline $\begin{array}{l}\text { Monarda fistulosa, } \\
\mathbf{2 0 1 9}\end{array}$ & 6.6 & 93 & 66.5 & $\mathrm{X}_{3}=(93-66.5): 6.6=4.00 \mathrm{ml} / \mathrm{g}$ \\
\hline
\end{tabular}


$4.0 \mathrm{ml} / \mathrm{g}, 4.25 \mathrm{ml} / \mathrm{g}$, and $4.8 \mathrm{ml} / \mathrm{g}$, respectively, for the herb of Thymus vulgaris, Satureja montana, Mentha piperita and Monarda fistulosa for $70 \%$ ethanol.

In our studies, we also elaborated the analytical procedure for the determination of the total flavonoid content in the tinctures. We adopted the elaborated analytical procedure for the determination of the total flavonoid content in bee bread tinctures for the tinctures of the tested four herbs (Hudz et al., 2017a,b; Hudz et al., 2020).

The study of the total flavonoid content should be carried out by identifying the dominant group of flavonoids by determining the maximum absorption in the differential spectrum after adding aluminum chloride. The maximum absorption is necessary to select an analytical marker with identical or close maximum absorption of its complex with aluminum chloride in an identical solvent. Spectrometric studies should be supplemented by further chromatographic ones to confirm the correct choice of analytical marker to recalculate the amount of flavonoids (Hudz et al., 2017a; Hudz 2020).

As a result of our study we established that the solutions of quercetin $(20 \mathrm{mg} / \mathrm{L})$, rutin $(50.2 \mathrm{mg} / \mathrm{L})$, and chrysin (80 $\mathrm{mg} / \mathrm{L}$ ) had the maximum absorption at the wavelengths of $425.9 \pm 0.3 \mathrm{~nm}$ at $77 \mathrm{~min}, 412.3 \pm 0.3 \mathrm{~nm}$ at $82 \mathrm{~min}, 388.4 \pm 0.7 \mathrm{~nm}$ at $81 \mathrm{~min}$, respectively.

The tinctures of Monarda fistulosa, Satureja hortensis, Thymus vulgaris, and Mentha piperita had one maximum absorption at $391.2 \pm 0.5 \mathrm{~nm}$ at $91 \mathrm{~min}, 389.9 \pm 0.5 \mathrm{~nm}$ at $76 \mathrm{~min}, 391.8 \pm 0.3 \mathrm{~nm}$ at $83 \mathrm{~min}, 394.9 \pm 1.1 \mathrm{~nm}$ at $78 \mathrm{~min}$, respectively, in the range of $360-440 \mathrm{~nm}$. The differential spectra are provided in Figure 3-5.

Therefore, the conducted spectrophotometric studies confirmed the domination of flavones in the tested tinctures. Considering the proximity of the maximum absorption of the tested tinctures and chrysin, this reference substance could be used for the determination and calculations of the total flavonoid content in tinctures.

\section{Conclusions}

The present study sets the basis for future research into the development ofantimicrobialandanti-inflammatory herbal products. The knowledge of the performed review about the chemical profile of essential oil and extracts of the studied species will aid in explaining the observed biological activity. The aqueous and ethanolic extracts and essential oil could be considered as cheap, easily accessible, and a potential source of

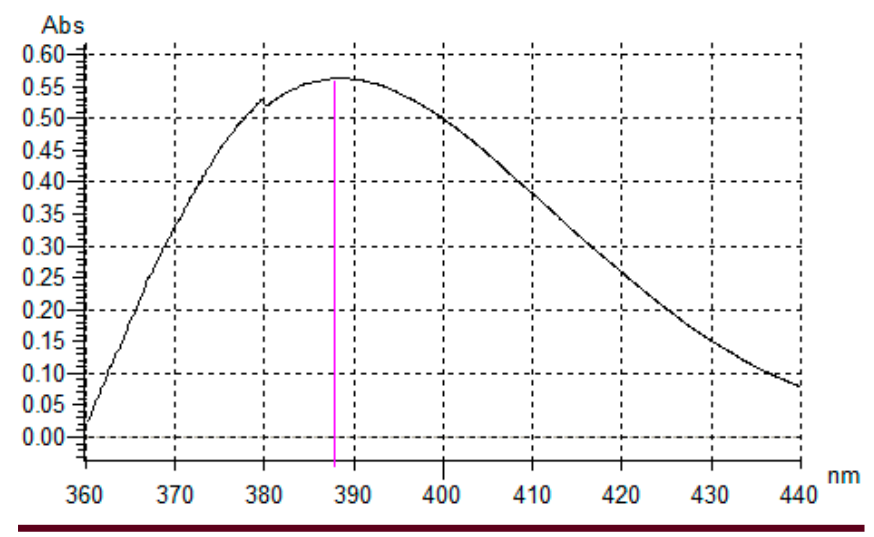

Figure 3 Differential spectrum of chrysin, concentration of chrysin $80 \mathrm{mg} / \mathrm{L}, \mathrm{A}=0.604 \pm 0.038$, time of the reaction $81 \mathrm{~min}, \lambda_{\max }=388.4 \pm 0.7 \mathrm{~nm}$

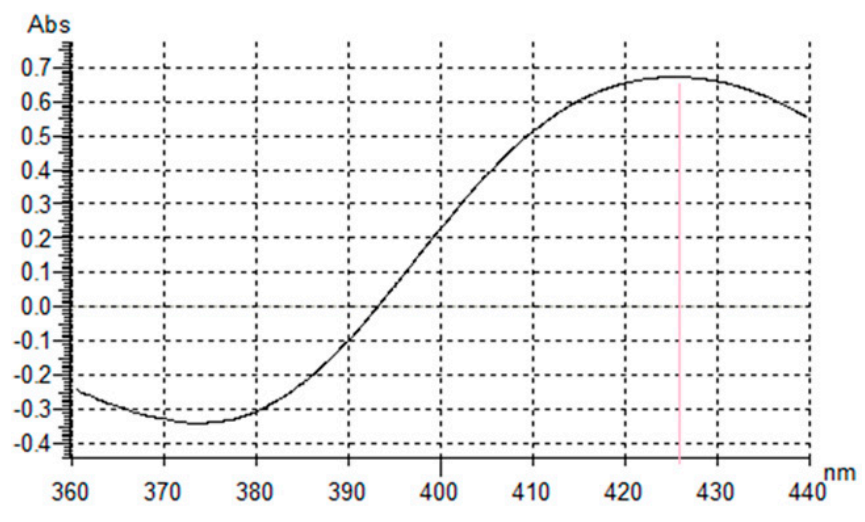

Figure 4 Differential spectrum of quercetin dihydrate, concentration of quercetin dihydrate $20 \mathrm{mg} / \mathrm{L}$, $\mathrm{A}=0.619 \pm 0.045$, time of the reaction $77 \mathrm{~min}$, $\lambda_{\text {max }}=425.9 \pm 0.3 \mathrm{~nm}$

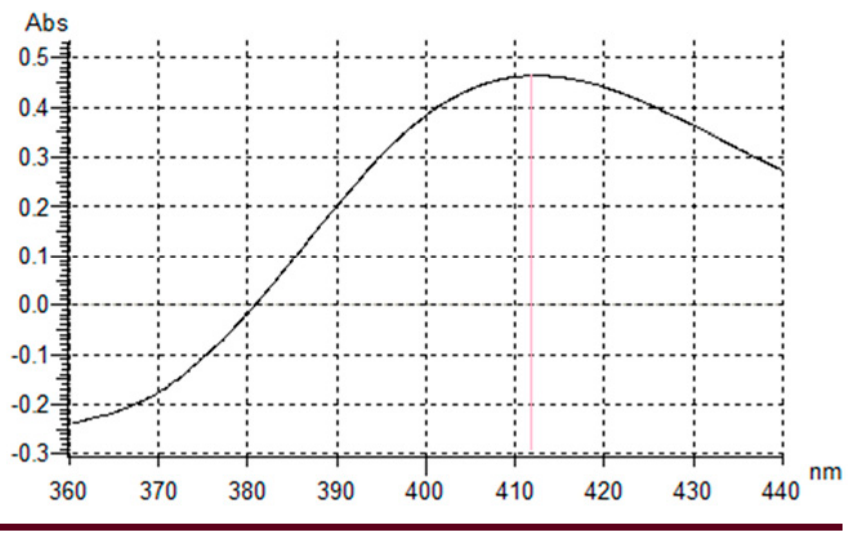

Figure 5 Differential spectrum of rutin trihydrate, concentration of rutin trihydrate $50.2 \mathrm{mg} / \mathrm{L}$, $\mathrm{A}=0.458 \pm 0.010$, time of the reaction $82 \mathrm{~min}$, $\lambda_{\text {max }}=412.3 \pm 0.3 \mathrm{~nm}$ 
natural antioxidants and antimicrobial compounds for the food and pharmaceutical industry. We established the coefficients of alcohol absorption as important technological parameters for the tested raw material with the purpose of the preparation of tinctures. The coefficient of alcohol absorption of the crushed raw material with the size of particles in the range of 0.5 to $5.0 \mathrm{~mm}$ was $2.8 \mathrm{ml} / \mathrm{g}, 4.0 \mathrm{ml} / \mathrm{g}, 4.25 \mathrm{ml} / \mathrm{g}$, and $4.8 \mathrm{ml} / \mathrm{g}$, respectively, for the herb of Thymus vulgaris, Mentha piperita, Satureja hortensis, and Monarda fistulosa for $70 \%$ ethanol. The solutions of quercetin $(20 \mathrm{mg} / \mathrm{L})$, rutin $(50.2 \mathrm{mg} / \mathrm{L})$, and chrysin $(80 \mathrm{mg} / \mathrm{L})$ had the maximum absorption at the wavelengths of $425.9 \pm 0.3 \mathrm{~nm}$ at $77 \mathrm{~min}, 412.3 \pm 0.3 \mathrm{~nm}$ at $82 \mathrm{~min}$, $388.4 \pm 0.7 \mathrm{~nm}$ at $81 \mathrm{~min}$, respectively, after adding aluminum chloride. The tinctures of Monarda fistulosa, Satureja hortensis, Thymus vulgaris, and Mentha piperita had the maximum absorption at $391.2 \pm 0.5 \mathrm{~nm}$ at $91 \mathrm{~min}, 389.9 \pm 0.5 \mathrm{~nm}$ at $76 \mathrm{~min}, 391.8 \mathrm{~nm}$ at $83 \mathrm{~min}$, $394.9 \pm 1.1 \mathrm{~nm}$ at $78 \mathrm{~min}$, respectively. Therefore, the performed spectrophotometric studies confirmed the domination of flavones in the tested tinctures, considering the proximity of the maximum absorption of the tested tinctures and chrysin. Future studies will be directed at the standardization of the developed tinctures and the establishment of their antimicrobial activity.

\section{Acknowledgment}

Co-author Nataliia Hudz thanks the International Visegrad Fund for the scholarship for the research related to the development of sprays on the base of natural products and performed at the University of Opole (Poland), 2020. The coathours are thankful to Liudmyla Svydenko for providing the herbs from the Sector of Mobilization and Conservation of Plant Resources of the Rice Institute of the NAAS, Plodove, Kherson region, 74992 Kherson, Ukraine.

\section{References}

BEN-ARYE, E., DUDAI, N., EINI, A., TOREM, M., SCHIFF, E., RAKOVER, Y. 2011. Treatment of upper respiratory tract infections in primary care: A randomized study using aromatic herbs. In Evid Based Complement Alternat Med., ID 690346. https://doi.org/10.1155/2011/690346

CASIAN, I., CASIAN, A., VALICA, V. 2020. Obtaining the wild bergamotessentialoilwith high contentofthymoquinone. In Moldovan Medical Journal, vol. 63(2), p. 40-43. https://doi.org/10.5281/zenodo.3866012

FIERASCU, I., DINU-PIRVU, C.E., FIERASCU, R.C., VELESCU, B.S., ANUTA, V., ORTAN, A., JINGA, N. 2018.Phytochemical profile and biological activities of Satureja hortensis L.: A review of the last decade. In Molecules, vol. 23(2458), p. 1-19. https://doi.org/10.3390/molecules23102458

FRANCATI, S., GUALANDI, G. 2017. Side effects of essential oils of Monarda fistulosa L. and M. didyma L. on the tachinid parasitoid Exorista larvarum (L.): a preliminary study. In Tachinid Times, vol. 30, p. 4-8.

HAMIDPOUR, R., HAMIDPOUR, S., HAMIDPOUR, M., SHAHLARI, M., SOHRABY, M. 2014. Summer savory: from the selection of traditional applications to the novel effect in relief, prevention, and treatment of a number of serious illnesses such as diabetes, cardiovascular disease, alzheimer's disease, and cancer. In Journal of Traditional and Complementary Medicine, vol. 4(3), p. 140-144. https://doi.org/10.4103/2225-4110.136540

HARBORNE, J.B. 1993. Introduction to ecological biochemistry, $4^{\text {th }}$ ed., Academic Press, London: San Diego

HASSANZADEH, M.K., NAJARAN, Z.T., NASERY, M. 2016. Summer savory (Satureja hortensis L.) oils. Essential oils in food preservation, flavor and safety. Ed. by Preedy V.R., Chapter 86, p. 757-763.

HONCHARENKO, V., TKACHENKO, H., NACHYCHKO, V., PROKOPIV, A., OSADOWSKI, Z. 2019. Antibacterial properties of ethanolic extracts obtained from leaves of some Thymus L. (Lamiaceae) representatives against Acinetobacter baumannii. In Agrobiodiversity for Improving Nutrition, Health and Life Quality, vol. 3, p. 14-24. https://doi.org/10.15414/ agrobiodiversity.2019.2585-8246.014-024

HUDZ,N., KORYTNIUK, O., YEZERSKA,O., MOTYKA, O., TURKINA, V., KORYTNIUK, R., WIECZOREK, P. P. 2020. Evaluation of the total flavonoid content and antimicrobial activity of the tinctures of propolis of Ukrainian origin. In Acta Poloniae Pharmaceutica, vol. 77(6), p. 897https://doi.org/10.32383/appdr/131651

HUDZ, N., KORZENIOWSKA, K., WIECZOREK, P.P., SCHUBERTOVÁ, Z., BRINDZA, J., IVANIŠOVÁ, E. 2017b. Methods of determination of sum of flavonoids in herbal products by spectrophotometric methods. In Agrobiodiversity for Improving Nutrition, Health and Life Quality, vol. 1, p. 168-173. http://dx.doi.org/10.15414/ agrobiodiversity.2017.2585-8246.168-173

HUDZ, N., NIKOLAIEVA, N., KONYK, C., KAPLUN, I., ŠIMKOVÁ, J., GRYGORIEVA, O. 2017a. Approaches to the identification and assay of flavonoids in bee bread extracts by spectrophotometric method. In Agrobiodiversity for Improving Nutrition, Health and Life Quality, vol.1, p. 174-178. http://dx.doi.org/10.15414/ agrobiodiversity.2017.2585-8246.174-177

KARPOVA, E.A., KUKUSHKINA, T.A., SHALDAEVA,T.M., PSHENICHKINA, Y.A. 2020. Biological active compounds and antioxidant activity of plants from the collection of Central Siberian Botanical Garden. II. Lamiaceae. In BIO Web of Conferences, vol. 24, 00033. https://doi.org/10.1051/bioconf/20202400033

LIU, X, SUN, Z.L., JIA, A.R., SHI, Y.P., LI, R.H., YANG, P.M. 2014. Extraction, Preliminary characterization and evaluation of in vitro antitumor and antioxidant activities of 
polysaccharides from Mentha piperita. In International Journal of Molecular Sciences, vol. 15, p. 16302-16319. https://doi.org/10.3390/ijms150916302

MARWA, C., FIKRI-BENBRAHIM, K., OU-YAHIA, D., FARAH, A. 2017. African peppermint (Mentha piperita) from Morocco: Chemical composition and antimicrobial properties of essential oil. In Journal of Advanced Pharmaceutical Technology \& Research, vol. 8(3), p. 8690. https://doi.org/10.4103/japtr.JAPTR_11_17

MCKAY, D.L., BLUMBERG, J.B. 2006. A review of the bioactivity and potential health benefits of peppermint tea (Mentha piperita L.). In Phytotherapy Research., vol. 20, p. 619633. https://doi.org/10.1002/ptr.1936

MORALES, R. 2002. Medicinal and aromatic plants industrial profiles, vol. 24-Thyme, E. Stahl-Biskup and F. Saez, eds., Taylor\&Francis, p. 16

POPOVICI, R.A., VADUVA, D., PINZARU, I., DEHELEAN, C.A., FARCAS, C.G., CORICOVAC, D., STANCA, H.T. 2019. A comparative study on the biological activity of essential oil and total hydro-alcoholic extract of Satureja hortensis L. In Experimental and Therapeutic Medicine, vol. 18, p. 932-942. https://doi.org/10.3892/etm.2019.7635

REZVANPANAH S., REZAEI K., GOLMAKANI M.-T., RAZAVI, S.H. 2011. Antibacterial properties and chemical characterization of the essential oils from summer savory extracted by microwave-assisted hydrodistillation. In Brazilian Journal of Microbiology, vol. 42(4), p. 1453-1462. https://dx.doi.org/10.1590/ $\underline{\mathrm{S} 1517-83822011000400031}$

ROCHA, J., EDUARDO-FIGUEIRA, M., BARATEIRO, A., FERNANDES, A., BRITES, D., BRONZE, R. 2015. Anti-inflammatory effect of rosmarinic acid and an extract of Rosmarinus officinalis in rat models of local and systemic inflammation. In Basic \& Clinical Pharmacology \& Toxicology, vol. 116(5), p. 398-413. https://doi.org/10.1111/bcpt.12335

SHAH, P.P., MELLO, P.M.O. 2004. A review of medicinal uses and pharmacological effects of Mentha piperita. In Natural Product Research, vol. 3, p. 214-221.

SHANAIDA, M., GOLEMBIOVSKA, O., HUDZ, N., WIECZOREK, P.P. 2018c. Phenolic compounds of herbal infusions obtained from some species of the Lamiaceae family. In Current Issues in Pharmacy and Medical Sciences, vol. 31(4), p. 194-199. https://doi.org/10.1515/cipms-2018-0036
SHANAIDA, M., HUDZ, N., JASICKA-MISIAK, I., WIECZOREK, P.P. 2021a. Polyphenols and pharmacological screening of a Monarda fistulosa L. dry extract based on a hydrodistilled residue by-product. In Frontiers in Pharmacology, vol. 12, p. 406. https://doi.org/10.3389/fphar.2021.563436

SHANAIDA, M., JASICKA-MISIAK, J., BIALON, M., KORABLOVA, O., WIECZOREK, P.P. 2021b. Chromatographic profiles of the main secondary metabolites in the Monarda fistulosa L. aerial part. In Research Journal of Pharmacy and Technology, vol. 14(4), p. 2179-2184. https://doi.org/10.52711/0974-360X.2021.00385

THOMPSON, J., CHALCHA, J., MICHET, A., LINHART, Y., EHLERS, B. 2003. Qualitative and quantitative variation in monoterpene co-occurrence and composition in the essential oil of Thymus vulgaris chemotypes. In Journal of Chemical Ecology, vol. 29(4), p. 859-80. http://dx.doi.org/10.1023/A:1022927615442

WIJESUNDARA, N. M., RUPASINGHE, H. 2019. Herbal Tea for the management of pharyngitis: inhibition of Streptococcus pyogenes growth and biofilm formation by herbal infusions. In Biomedicines, vol. 7(3), p. 63. https://doi.org/10.3390/biomedicines7030063

YEZERSKA, O., DARMOGRAJ, R., HUDZ, N. 2021. Development of technology and investigation of Monarda fistulosa tincture. In PLANTA+. science, practice and education: The proceedings of the International Scientific and Practical Conference (Kyiv, February 19, 2021). Kyiv, p. 220-222.

ZHILYAKOVA, E.T., NOVIKOV, O.O., NAUMENKO, E.N., KRICHKOVSKAYA, L.V., KISELEVA, T.S., TIMOSHENKO, E.YU., NOVIKOVA, M.YU., LITVINOV, S.A. 2009. Study of Monarda fistulosa essential oil as a prospective antiseborrheic agent. In Bulletin of Experimental Biology and Medicine, vol. 148(4), p. 612-614. 